
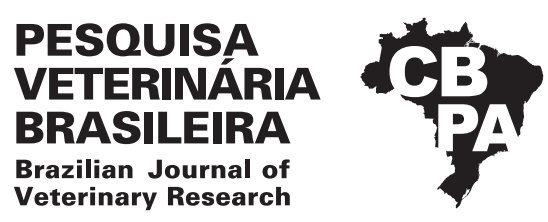

Pesq. Vet. Bras. 38(11):2155-2158, novembro 2018 DOI: $10.1590 / 1678-5150-P V B-5995$

ISSN 0100-736X (Print)

ISSN 1678-5150 (Online)

\title{
Nephroblastoma in a black-tufted marmoset (Callithrix penicillata) ${ }^{1}$
}

\author{
Jair A. Ferreira Junior², Daniel R. Rissi³ ${ }^{3}$ Mônica A. Elias², André S. Leonardo², \\ Karla A. Nascimento ${ }^{2}$, Juliana T.S.A. Macêdo ${ }^{2}$ and Pedro M.O. Pedroso ${ }^{2 *}$
}

\begin{abstract}
Ferreira Junior J.A., Rissi D.R., Elias M.A., Leonardo A.S., Nascimento K.A., Macêdo J.T.S.A. \& Pedroso P.M.O. 2018. Nephroblastoma in a black-tufted marmoset (Callithrix penicillata). Pesquisa Veterinária Brasileira 38(11):2155-2158. Laboratório de Patologia Veterinária, Hospital Veterinário, Fundação Universidade de Brasília, Via L4 Norte, Brasília, DF 70910-970, Brazil. E-mail: pedrosovet@yahoo.com.br

A renal nephroblastoma is described in a free-living black-tufted marmoset (Callithrix penicillata) in Central Brazil. The monkey was found dead and subjected to necropsy. Gross anatomic changes consisted of a ruptured left kidney, which was almost completely effaced by a white to yellow, partially encapsulated friable mass. The left ureter was distended due to obstruction by a red, spherical, $2 \mathrm{~mm}$ in diameter friable mass. The urinary bladder was also distended. Histologically the renal and ureteral masses consisted of a triphasic embryonal neoplasm composed of embryonic epithelium forming glomeruli and tubules, polygonal blastemal cells, and a mesenchymal stroma. The embryonic epithelium exhibited rare nuclear immunoreactivity for WT-1, whereas blastemal cells exhibited robust cytoplasmic and rare nuclear immunoreactivity for WT-1; blastemal cells were also immunoreactive for vimentin. No immunoreactivity was detected for pan-cytokeratin (AE1/AE3), actin, and desmin. Morphological and immunohistochemical features of the present neoplasm are consistent with those described for renal nephroblastoma.
\end{abstract}

INDEX TERMS: Nephroblastoma, black-tufted marmoset, Callithrix penicillata, neoplasm, non-human primate, Wilms tumor, pathology.

\begin{abstract}
RESUMO.- [Nefroblastoma em um sagui-de-tufospretos (Callithrix penicillata).] Descreve-se um caso de nefroblastoma maligno em um sagui de vida livre no Brasil Central. 0 macaco foi encontrado morto e encaminhado para necropsia. Na macroscopia, o rim esquerdo apresentava-se rompido e o parênquima estava substituído por um tecido neoplásico friável, parcialmente encapsulado e de superfície natural branca e de corte amarela. O ureter esquerdo apresentava-se distendido devido à obstrução por uma massa friável, vermelha, esférica, de $2 \mathrm{~mm}$ de diâmetro. Histologicamente, as massas renal e ureteral consistiam de uma neoplasia embrionária composta por três populaçõies de células neoplásicas, composta por epitélio embrionário formando glomérulos e túbulos, células blastemais poligonais
\end{abstract}

\footnotetext{
${ }^{1}$ Receveid on June 5, 2018.

Accepted for publication on August 12, 2018.

${ }^{2}$ Laboratório de Patologia Veterinária, Universidade de Brasília (UnB), Via L4 Norte, Brasília, DF 70910-970, Brazil. *Corresponding author: pedrosovet@yahoo.com.br

${ }^{3}$ Department of Pathology, Athens Veterinary Diagnostic Laboratory, University of Georgia College of Veterinary Medicine, Athens, GA, USA.
}

e um estroma mesenquimal. 0 epitélio embrionário exibiu imunorreactividade nuclear rara para WT-1, enquanto que as células blastemais exibiram imunorreactividade nuclear citoplasmática e rara para WT-1; As células blastemais também foram imunorreativas à vimentina. Nenhuma imunorreatividade foi detectada para pan-citoqueratina (AE1/AE3), actina e desmina. As características morfológicas e imuno-histoquímicas da presente neoplasia são consistentes com as descritas para o nefroblastoma renal.

TERMOS DE INDEXAÇÃO: Nefroblastoma, sagui-de-tufos-pretos, Callithrix penicillata, neoplasma, primata não-humano, tumor de Wilms, patologia.

\section{INTRODUCTION}

Nephroblastoma is an embryonic tumor that is commonly described in humans, especially in children (Goens et al. 2005). Nefroblastoma has been uncommonly described in non-human primates (NHP), such as cynomolgus monkeys (Macaca fascicularis) (Bennett et al. 1982, Zoller et al. 2008), baboons (Papio sp.) (Goens et al. 2005), cotton-top marmosets 
(Saguinus oedipus) (Jones \& Casey 1981), and in a common tamarin (Callithrix jacchus) (Zoller et al. 2008). In NHP, renal nephroblastomas are usually an incidental finding in young individuals. They appear not only as spontaneous cases, but also in association with radiation exposure, carcinogenic chemical agents and parasites (Jones \& Casey 1981, Zoller et al. 2008). In dogs, tumors typically affect the thoracolumbar spinal cord and cause clinical signs related to spinal cord compression (JPC 2017).

Nephroblastoma arises from the primitive metanephric blastema and typically exhibits epithelial and stromal differentiation in varying proportions (Meuten et al. 2004). Renal tumors can be solitary or multiple and unilateral or bilateral. Histologically, nephroblastoma is characterized by the presence of three cell populations (Meuten et al. 2004, JPC 2017). The embryonic epithelial component exhibits glomerular or tubular differentiation (Zoller et al. 2008); the blastemal component consists of densely packed, round to polygonal cells with a serpentine, diffuse, or nodular arrangement; and the mesenchymal component is arranged in streams of spindle cells that can undergo differentiation to other mesenchymal tissues such as skeletal muscle, cartilage, and/or bone (Meuten et al. 2004).

Callithrix penicillata (Geoffroy 1812) is a New World primate known as "black-tufted marmoset" or "star tamarin" due to its long, black pre-auricular hair ornaments in the shape of a brush. These NHP are insectivorous-gumivores and inhabit the Amazon Forest, the Atlantic Forest, and the Brazilian Cerrado, usually forming groups of approximately 10 individuals (Nitta et al. 2013). Primates of the genus Callithrix are phylogenetically close to humans and have the ability to adapt in urban or secondary vegetation environments, often acting as invasive species and as reservoirs of zoonotic diseases such as yellow fever, rabies, and dengue (Do Vale 2016). The purpose of the report is to describe a case of renal nephroblastoma in a free-living black-tufted marmoset in Central Brazil.

\section{MATERIALS AND METHODS}

A young female black-tufted marmoset (Callithrix penicillata) was found dead in the territory of the Federal District and subjected to necropsy. Representative samples of various organs were collected, fixed in 10\% buffered formalin, routinely processed for histology, and stained with hematoxylin and eosin (HE). Immunohistochemistry (IHC) was performed using the streptavidin-biotin-peroxidase technique (LSAB+System HRP, EasyLink One, Esaypath) for anti-WT-1 (Wilms tumor factor; manufacturer's pre-dilution, Cell Marque, USA), anti-cytokeratin (AE1/AE3, 1:100 dilution, Biocare Medical, USA), and anti-vimentin (1:100 dilution, Biocare Medical, USA), anti-human smouth muscle actin (1:500 dilution, clone 1A4, DakoCytomation), and anti-desmin (1:50 dilution, Biocare Medical, USA). Immunostaining was visualized with the use of 3-3'-diaminabenzidine (DAB). Sections were stained with Harris hematoxylin. Positive and negative controls were used for each antibody.

\section{RESULTS}

Gross anatomic changes consisted of $10 \mathrm{ml}$ of serosanguineous fluid in the abdominal cavity and blood clots covering the omentum and the intestinal loops. The left kidney was ruptured was and almost completely effaced by a white to yellow, partially encapsulated friable mass that had a yellow cut surface. Between the affected kidney and the liver, other soft and friable white masses were present. The left ureter was distended due to obstruction by a red, spherical, $2 \mathrm{~mm}$ in diameter friable mass. The urinary bladder was also distended (Fig.1). The hepatic capsule was moderately pale.

Microscopically a poorly demarcated, partially encapsulated, infiltrative neoplasm effaced and replaced most of the renal parenchyma. The tumor consisted of three intertwined cell populations (Fig.2): an embryonic epithelial component was composed of flat to cuboidal epithelial cells that formed primitive glomerular (Fig.3) and tubular structures; a second cell population was characterized by round to polygonal blastemal cells; and a third population of cells composed of

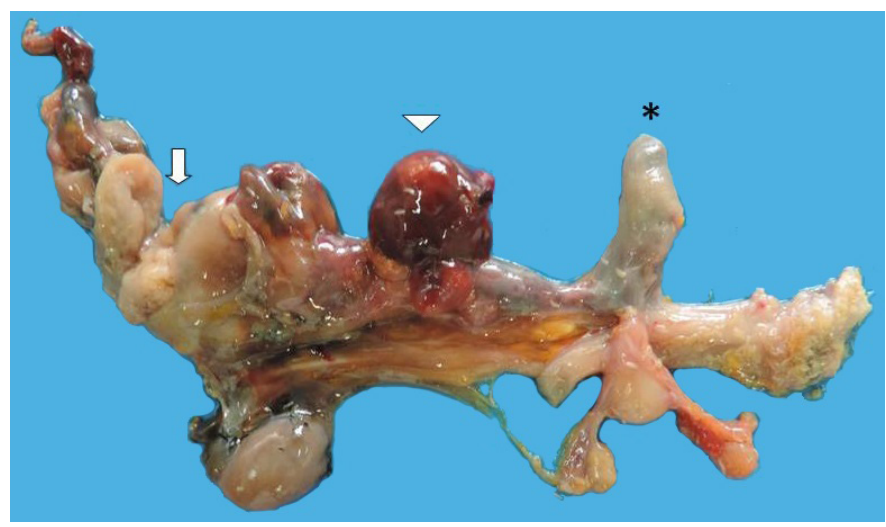

Fig.1. Renal nephroblastoma in a black-tufted marmoset (Callithrix penicillata), genito-urinary system. The left kidney is effaced by a friable white mass (arrow). A red mass also expands the mid-third portion of the ureter (arrowhead). The urinary bladder is shown as a reference (asterisk).

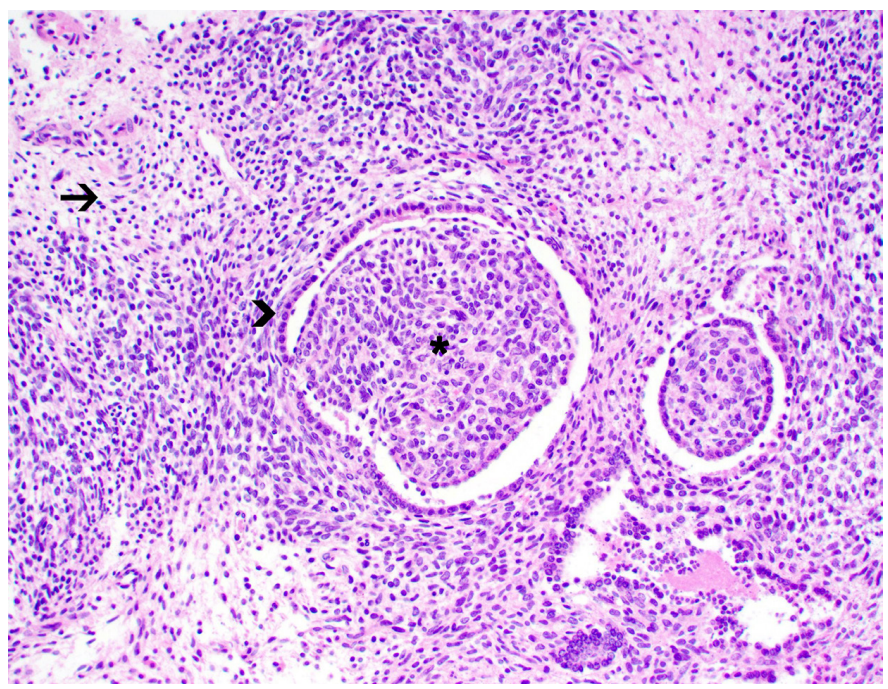

Fig.2. Renal nephroblastoma in a black-tufted marmoset (Callithrix penicillata). Scattered throughout the neoplasm are tubules lined by epithelial cells (arrowhead) and lined by epithelial cells and containing nests of polygonal blastemal cells (asterisks). The mesenchymal component (arrow) consists of streams of spindle cells. HE, obj.20x. 


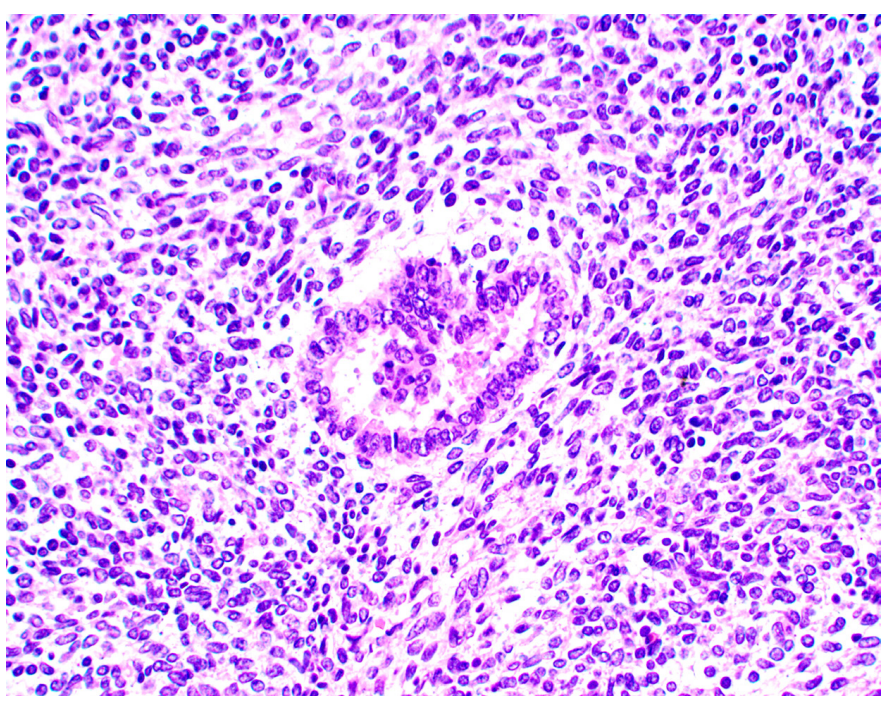

Fig.3. Renal nephroblastoma in a black-tufted marmoset (Callithrix penicillata). The neoplasm is composed of irregular glomerular tufts lined by epithelial cells. HE, obj.20x.

thin bundles of fibroblasts, collagen, and small blood vessels (mesenchymal stroma). The epithelial cells had poorly defined and eosinophilic cytoplasm, and oval nuclei with coarse chromatin and 1 to 3 nucleoli. The blastemal cells were densely packed, had indistinct cytoplasmic borders, and round nuclei with loosely arranged chromatin and 1 to 2 nucleoli. There was moderate anisocytosis and anisokaryosis, and 5 mitoses in 10 400x fields. Adjacent renal tissue was compressed and atrophied, with multifocal infiltrates of moderate numbers of lymphocytes, plasma cells, and macrophages. The lumen of the ureter and urinary bladder contained large numbers of erythrocytes and strands of fibrin that extended into the urothelium and lamina propria. In these areas there were foci of neoplastic transformation similar to those described for the kidney.

The embryonic epithelium exhibited rare nuclear immunoreactivity for WT-1 (Fig.4), whereas blastemal cells exhibited robust cytoplasmic and rare nuclear immunoreactivity for WT-1; blastemal cells were also immunoreactive for vimentin (Fig.5). No immunoreactivity was detected for pan-cytokeratin (AE1/AE3), actin, and desmin.

\section{DISCUSSION}

The diagnosis of nephroblastoma in this case was made based on the morphological and IHC findings. Nephroblastomas are poorly described in free-living tamarins in South America. In Brazil, these neoplasms are highly prevalent in pigs and poultry during slaughter (Brum et al. 2015, Serakides \& Silva 2017). The primary renal tumors most commonly described in NHP are adenomas and carcinomas; nephroblastomas are rarely described (Jones \& Casey 1981, Zoller et al. 2008). In humans, nephroblastomas affect mainly children, where carcinogenesis has been related to abnormalities in the Wilms tumor gene (WT-1 in chromosome 11). However, the genetics of nephroblastoma or Wilms tumor appear to be multifactorial and probably include other chromosomal abnormalities. Phylogenetic studies with two NHP with nephroblastoma

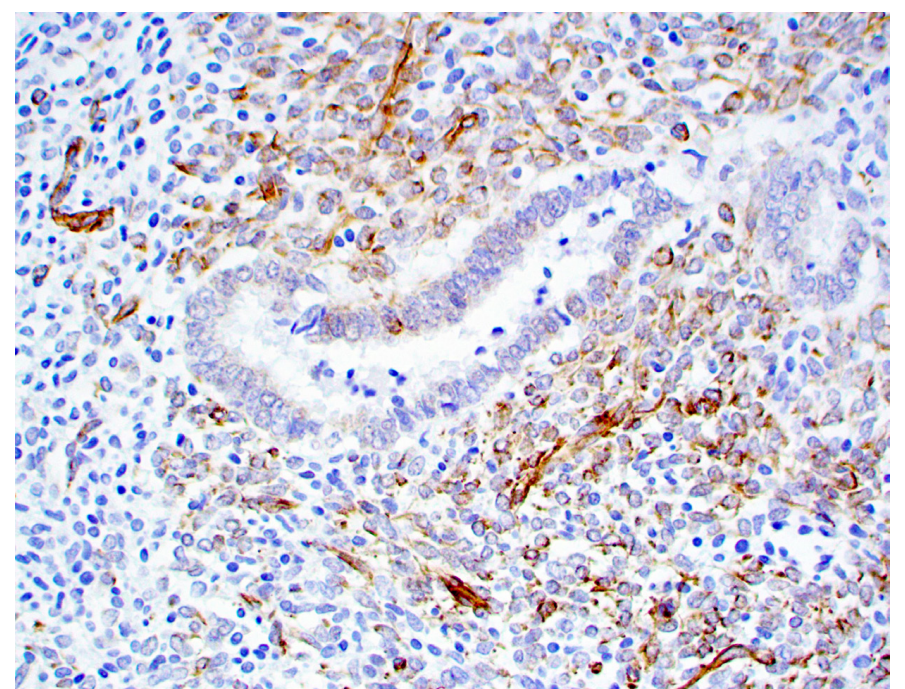

Fig.4. Renal nephroblastoma in a black-tufted marmoset (Callithrix penicillata). There is rare nuclear immunostaining for WT-1 within tubular cells and cytoplasmic immunostaining within blastemal cells. Immunohistochemistry, streptavidin-biotinperoxyase method, Harris haematoxylin counterstaining, obj.20x.

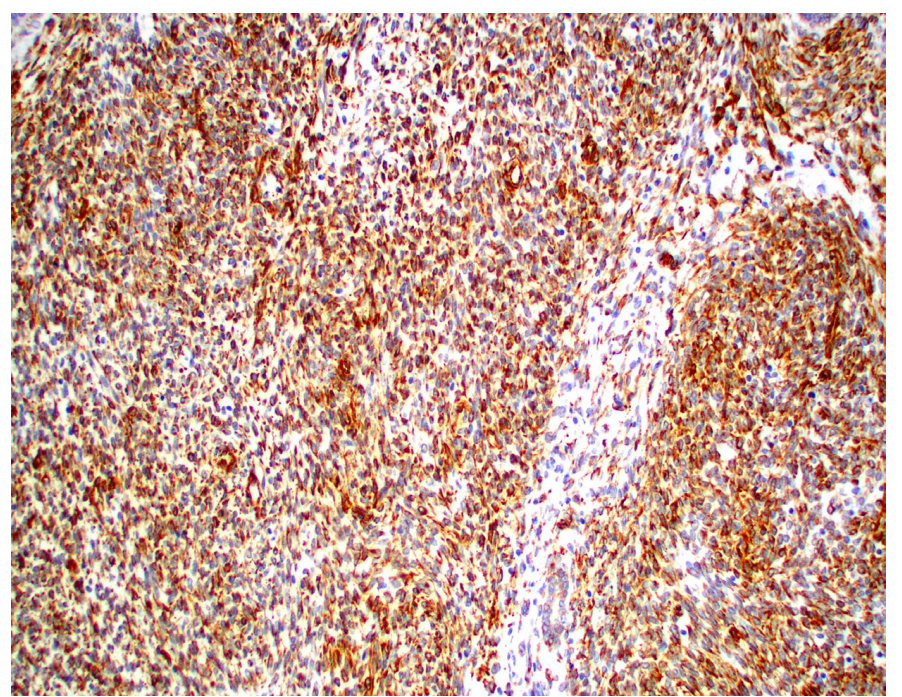

Fig.5. Renal nephroblastoma in a black-tufted marmoset (Callithrix penicillata). Positive immunostaining for vimentin within peritubular blastemal cells. Immunohistochemistry, streptavidin-biotin-peroxidase method, Harris haematoxylin counterstaining, obj.20x.

(Macaca fascicularis and baboon) with pairs of identical chromosomes and homologous to human chromosome $11 \mathrm{did}$ not reveal any chromosomal abnormalities similar to those associated with those tumors in humans (Goens et al. 2005). Primary renal neoplasms, including nephroblastoma, have also been associated with radiation, carcinogenic chemicals, and parasites in NHPs (Jones \& Casey 1981, Zoller et al. 2008) and with N-ethylnitrosouria in laboratory mice (Zoller et al. 2008, Meuten \& Meuten 2017). A familial form of nephroblastoma occurs in some strains of laboratory mice (Zoller et al. 2008, Meuten \& Meuten 2017). 
In the few reported cases in NHPs, nephroblastomas were directly related to the death of the animals (Jones \& Casey 1981, Zoller et al. 2008). In the present case, the tumor likely caused death due to its invasive and destructive nature, with hemorrhage into the abdomen and hypovolemic shock. Although nephroblastomas are usually unilateral, located at one pole of the kidney, tumors can occasionally compress adjacent organs or invade the renal capsule, adhering to the abdominal wall and mesentery and, exceptionally, invading the pelvis (Meuten \& Meuten 2017). Microscopically, the tumor exhibited the classic triphasic features typically described in cases of nephroblastoma in humans and other animals (Jones \& Casey 1981, Goens et al. 2005, Zoller et al. 2008, Meuten \& Meuten 2017). A striking feature in this case was the metastatic foci observed in the ureter, which is a feature of malignancy in these tumors (Meuten \& Meuten 2017). In pigs, birds and primates, metastases are rare, but in dogs and cats, metastasis is expected in more than $50 \%$ of cases (Goens et al. 2005, Zoller et al. 2008, Meuten \& Meuten 2017).

WT-1 IHC is useful for diagnostic confirmation of nephroblastoma. However, immunolabeling patterns have been mainly described for spinal cord nephroblastomas in dogs, where nuclear staining occurs within neoplastic cells forming glomerular and tubular structures and blastemal cells (Brewer et al. 2011). In the current case, the typical nuclear WT-1 immunolabeling was rare throughout the embryonic epithelium and, in addition, nuclear and cytoplasmic WT-1 immunostaining was detected within the blastemal component. While nuclear staining is considered specific for the diagnosis of nephroblastoma, studies have shown that WT-1 can be also expressed in the cytoplasm of neoplastic cells (Niksic et al. 2004) and can occur within all three tumor components (Sangkhathat et al. 2010).

\section{CONCLUSIONS}

The morphological and IHC features of the current neoplasm were typical of those described for renal nephroblastoma.

Although rare, nephroblastoma should be considered in the differential diagnosis of primary renal neoplasms in NHPs.

\section{REFERENCES}

Bennett B.T., Beluhan F.Z. \& Welsh T.J. 1982. Malignant nephroblastoma in Macaca fascicularis. Lab. Anim. Sci. 32(4):403-404. <PMid:6292577>

Brewer D.M., Cerda-Gonzalez S., Dewey C.W., Diep A.N., Van Horne K. \& McDonough S.P. 2011. Spinal cord nephroblastoma in dogs: 11 cases
(1985-2007). J. Am. Vet. Med. Assoc. 238(5):618-624. <http://dx.doi. org/10.2460/javma.238.5.618> <PMid:21355804>

Brum J.S., Martins T.B., Vielmo A., Hammerschmitt M.E., Talini R., Minozzo C.D. \& Barros C.S.L. 2015. Neoplasmas em suínos: 37 casos. Pesq. Vet. Bras. 35(6):541-546. <http://dx.doi.org/10.1590/S0100-736X2015000600009>

Do Vale C.A. 2016. Distribuição e potencial de invasão do sagui Callithrix penicillata (É. Geoffroy, 1812) no território brasileiro. Dissertação de Mestrado, Universidade Federal de Juiz de Fora, Juiz de Fora. 53p.

Goens S.D., Moore C.M., Brasky K.M., Frost P.A., Leland M.M. \& Hubbard G.B. 2005. Nephroblastomatosis and nephroblastoma in nonhuman primates. J. Med. Primatol.34(4):165-170. <http://dx.doi.org/10.1111/j.1600-0684.2005.00113. $\mathrm{x}><$ PMid:16053493>

Jones S.R. \& Casey H.W. 1981. Primary renal tumors in nonhuman primates. Vet. Pathol.18(Suppl. 6):89-104.<http://dx.doi.org/10.1177/0300985881018s0610> <PMid:6283711>

JPC 2017. Case IV. 14th Wednesday Slide Conference, Joint Pathology Center Veterinary Pathology Services, Maryland. Available at <https://www.askjpc. org/wsco/wsc/wsc16/16WSC14.pdf> Access on Jun. 5, 2018.

Meuten D.J. \& Meuten T.L.K. 2017. Tumors of the urinary system, p.632-688. In: Meuten D.J. (Ed.), Tumors in Dosmestic Animals. 5th ed. John Wiley and Sons, Ames.

Meuten D.J., Everitt J., Inskeep W., Jacobs R.M., Peleteiro M. \& Thompson K.G. 2004. Histological Classification of Tumors of the Urinary System of Domestic Animals. Armed Forces Institute of Pathology, WHO, Washington, D.C. 70p.

Niksic M., Slight J., Sanford J.R., Caceres J.F. \& Hastie N.D. 2004. The Wilms' tumour protein (WT1) shuttles between nucleus and cytoplasm and is present in functional polysomes. Hum. Mol. Genet. 13(4):463-471. <http:// dx.doi.org/10.1093/hmg/ddh040> <PMid:14681305>

Nitta C.Y., Silva L.C.S., Miglino M.A., Ambrosio C.E., Bombonato P.P. \& Rici R.E.G. 2013. Comparative ultrastructure of the tongue of black-tuftedear-marmoset (Callithrix penicillata) and black-howler-monkey (Alouatta caraya) in different age groups. Pesq. Vet. Bras. 33(Suppl. 1):75-84. <http:// dx.doi.org/10.1590/S0100-736X2013001300013>

Sangkhathat S., Kanngurn S., Chaiyapan W., Gridist P. \& Maneechay W. 2010. Wilms' tumor 1 gene (WT1) is overexpressed and provides an oncogenic function in pediatric nephroblastomas harboring the wild-type WT1. Oncol. Lett. 1(4):615-619. <http://dx.doi.org/10.3892/ol_00000109> <PMid:22966353>

Serakides R. \& Silva J.F. 2017. Sistema urinário, p.267-310. In: Santos R.L. \& Alessi A.C. (Eds), Patologia Veterinária. 2ª ed. Roca, Rio de Janeiro.

Zoller M., Matz-Rensing K., Fahrion A. \& Kaup F.J. 2008. Malignant nephroblastoma in a common marmoset (Callithrix jacchus). Vet. Pathol. 45(1):80-84. <http://dx.doi.org/10.1354/vp.45-1-80><PMid:18192583> 